Vincze, Kata Zsófia. "Transylvanianism, Nationalism, Folklore: The Academic Career of Olga Nagy in the Light of Her Posthumous Book, Vallomások (2010)." Hungarian Cultural Studies. e-Journal of the American Hungarian Educators Association, Volume 6 (2013): http://ahea.pitt.edu DOI: 10.5195/ahea.2013.122

\title{
Transylvanianism, Nationalism, Folklore: The Academic Career of Olga Nagy in the Light of Her Posthumous Book, Vallomások (2010)
}

\author{
Kata Zsófia Vincze
}

\begin{abstract}
The volume Vallomások ['Testimony'], published posthumously in 2010, is the folklorist Olga Nagy's (1921-2006) last book. In this paper I will analyze Nagy's academic significance in the light of her own last self reflection presented in Vallomások. This volume provides an exciting overview of the internal dynamics of East-Central European culture and interethnic relations. While I examine Nagy's life work, especially her academic work on rural women and her new ideas regarding the alive folklore, I will also reflect on the ideology of so called Transylvanianism that constitutes the framework of many Hungarian writings from Romania. Transylvanianism is a complex ideology rooted in the Hungarian national movement of the nineteenth century, one that later turned into a complex manifestation of the Hungarian minorities in Romania through literature, culture, politics and self-definition. Elaborated by writers, historians and journalists, Transylvanianism after 1918 — and even more vehemently after 1947-aimed to preserve and reinforce Hungarian national pride and identity in the region through cultural activities, education and political action.
\end{abstract}

Keywords: Transylvanianism, Romanian feminism, Hungarian minority in Romania, Hungarian folklore in Romania, rural women

Biography: Kata Zsófia Vincze teaches in the Department of Ethnology at Eötvös Loránd University in Budapest. She was born in Kolozsvár (Klausenburg), Romania, and graduated from Babes Bolyai University. She received her $\mathrm{PhD}$ in Contemporary Jewish Studies in 2006 at the Eötvös Lóránd University, Ethnology Department. She has also studied and has done field work in Israel, Spain and South Africa. She has co-authored Dialogues on Teaching Critical Literature (2003) and has two single-authored books, Tradition, Memory, Identity. The Foundation Myth of Exodus (2004), and Visszatérök a tradícióhoz [Return to Tradition] (2009). She has also published several articles on medieval literature, ethnology and cultural anthropology.

The volume Vallomások is the folklorist Olga Nagy's (1921-2006) last book, published posthumously in 2010. In this paper I will analyze Nagy's academic significance in the light of her own last self reflection presented in Vallomások ['Testimony'], which provides an exciting overview of the internal dynamics of East-Central European culture and interethnic relations. In many of her books, Nagy — as a Hungarian from Romania, and as a Transylvanian folklorist and ethnologist - constantly reflected on her life and work, examining both with brutal honesty and doubt, especially with regard to her academic career as a woman and a Hungarian under 
Vincze, Kata Zsófia. "Transylvanianism, Nationalism, Folklore: The Academic Career of Olga Nagy in the Light of Her Posthumous Book, Vallomások (2010)." Hungarian Cultural Studies. e-Journal of the American Hungarian Educators Association, Volume 6 (2013): http://ahea.pitt.edu DOI: 10.5195/ahea.2013.122

Communist rule in Romania. In 1991 she published an earlier book, with a similar title, Gyónas ['Confessions'] and in 1995 Pályakép fénnyel es árnyékkal ['Career Portrait with Lightness and Darkness']. In Nagy's last book, Vallomások, one which delineates her personal life and research career, she evaluates her own academic achievements, reacts to her critics, and discusses and repeatedly quotes from her works as she contemplates her views on God, religion, the peasantry, the status of minorities, liberalism and the status of women. Vallomások connects Nagy's academic work to her personal life circumstances during communism, such as her dealing with the trauma of Transylvania's annexation to Romania, her encounters with the Romanian secret service, her silent protests against the communist regime, the Hungarian ideology of "Transylvanianism" which she adopted, and her difficult personal life.

The Transylvanianist idea is based on the exceptional historical situation of Transylvanian Hungarians. For Hungarians and Romanians alike, Transylvania, a historical region bounded on the east and south by the Carpathian mountains, is charged with special national semantics as the land of ancient traditions. From the Hungarian perspective, Transylvania was lost twice. The first loss came as a result of the post-World War I Treaty of Trianon. Hungary temporarily recouped Transylvania after the Second Vienna Arbitration Accord (1940), an agreement in which Nazi Germany sanctioned Hungary's re-annexation of territories it had lost in 1920. The Award was overturned following the defeat of Germany in 1945, and in the Treaty of Paris (1947) the Allies restored the Trianon frontier and Transylvania was once again re-annexed to Romania.

Transylvanianism is a complex ideology rooted in the Hungarian national movement of the nineteenth century, one that later turned into a diverse manifestation of the Hungarian minorities in Romania through literature, culture, politics and self-definition. Elaborated by writers, historians and journalists after 1918 and even more vehemently after 1947, the movement aimed to preserve and reinforce Hungarian national pride and identity in the region through cultural activities, education and political action. While in her Erdélyi sors: tegnap, ma, holnap 2001 [Transylvanian fate yesterday, today and tomorrow] Nagy herself as a folklorist analyzed Transylvanianism as an ideology that creates the mythic image of Transylvania, her lifelong academic work is also part of this ideology. Seen in the context of Transylvanianism, Nagy's Vallomások is an account, reevaluation, and cruel interrogation of her own life work, her role within Transylvanianism and her impact on the Hungarian Romanian intellectual circles. Writing the Vallomások in her old age, Nagy reevaluates her role and the significance of her academic work within Romania and Hungary in a very personal and sincere tone. The honesty of Nagy's confessional mode can be shocking for the reader who is not familiar with the postwar traumas and the morality of Transylvanianism. Nagy repeatedly makes the claim that through her work she "sacrificed her life" for the mission of "saving" and "preserving " Hungarian culture in Romania. In this book, published two decades after the fall of communism, she looks back at the academic treadmill, the sacrifices, risks and at the immense oeuvre she had produced, and she evaluates her "deterministic mission" (sorsszerü küldetés). In particular, she evaluates the worthiness of her determinist mission and its cultural and political weight.

It is important to understand the ideological context that enabled the nationalist Transylvanianist social discourse to continue to exist even during communism, couched in codes in ethnography, literature and the social sciences even while persecuted and often forbidden as a voice of the opposition. Even after 1989, when the message of Transylvanianism could be spread openly, folklore and ethnographic research in Romania always supported the nationalist theories. In fact, alongside academic folklore research, there continues to exist some pseudo-scientific 
Vincze, Kata Zsófia. "Transylvanianism, Nationalism, Folklore: The Academic Career of Olga Nagy in the Light of Her Posthumous Book, Vallomások (2010)." Hungarian Cultural Studies. e-Journal of the American Hungarian Educators Association, Volume 6 (2013): http://ahea.pitt.edu DOI: 10.5195/ahea.2013.122

branch of Central-Eastern European ethnography, loaded with national ideologies that romanticizes "the folk" and idealizes and overly aestheticizes their "ancient", "purely" Hungarian and "pristine" folklore that was not "contaminated" by foreign impact and modernity. However, Nagy's work, for all she talked about her mission to save Hungarian culture in Romania, does not in any way belong to these trends.

To understand Olga Nagy and her work, we must first understand the special situation of Transylvanian Hungarians. Between 1941 and 1945, Nagy, then the wife of a Protestant pastor and a mother with four children, lived in a village called Kisiklód, where she worked as a schoolteacher while studying theology during what was referred to as Magyarvilág [Hungarian world] or Magyaridők [Hungarian times], when parts of Transylvania were once again annexed to Hungary. When, in 1947, Transylvania permanently became part of Romania (a period referred to as Románvilág [Romanian time]), Nagy and her husband settled down in one of the most ethnically traditional Hungarian villages called Szék. Nagy received a degree in ethnography in 1948 and, from 1952 to 1953, worked for the literary journal Utunk ['Our Path']. Between 1954 and 1958 she worked for Dolgozó Nö [Working Woman]. In 1958, she became a researcher at the Folklore Institute of the Romanian Academy of Sciences, where she participated in institutional, collective and individual research programs. She did fieldwork in the Transylvanian villages of the regions of Mezőség, Marosszék and Kalotaszeg, where she recorded Hungarian-language stories, beliefs, traditions, and various other folklore phenomena.

Vilmos Keszeg, a leading ethnologist from Romania and researcher of Olga Nagy's life work, edited a volume within the ethnology series Néprajzi Látóhatár ['Ethnologic Horizon'] devoted to Olga Nagy's work in honor of her eightieth birthday (Keszeg and Viga 2001). This volume includes Nagy's full bibliography up to 2001, while her bibliography after 2001 can be found in the Necrology written by Ferenc Pozsony in Acta Siculica (Pozsony 2007, 757-760). Keszeg has written several other articles and reviews on Nagy's work (see Keszeg 1994, 118 $121 ; 2000,102-106 ; 2002,61-64)$. According to Keszeg's calculation Nagy recorded and published some three thousand folk narratives in the space of thirty years. From the end of the seventies to the second half of the eighties, she and János Péntek organized and managed the socio-ethnographical circle Korunk [Our Era] that had a significant role in the paradigm shift of the new generation in Romanian social sciences. Nagy was also an active member of the Kriza János Néprajzi Társaság [János Kriza Ethnographic Association], established in 1990.

The Hungarian minority in Romania idolized teachers, educators and ministers as role models, whose primary mission was to protect Hungarian identity, language, culture and tradition. So it is not surprising that from the above-mentioned biographical essays on Nagy we might assume that she identified deeply with the role of Hungarian "shining beacon of light" in the "Romania's time of darkness", and was an enlightening, self-sacrificing intellectual. The enemy was seen as the new state the Transylvanians found themselves in, where the Hungarians felt under double suppression, both from the communist dictatorship and the Romanian rule, with the biggest cultural threat felt to be the so-called "Romanianization", that is, what they felt was the forced assimilation into the Orthodox Romanian speaking majority, and the expansion of the Romanian population in Transylvania. Nagy's books are no exception to other Hungarian writings when it comes to demonizing the "unsophisticated" Romanian Orthodox culture, contrasted with what is considered a superior Hungarian Christian (and Western) culture and language. This attitude of defensive superiority is one that persists to this day in both popular and academic Hungarian writings, reflected in many catch phrases such as "we are victims of a screaming injustice signed in the Trianon Treaty, " "our lands were taken," "Transylvania has 
Vincze, Kata Zsófia. "Transylvanianism, Nationalism, Folklore: The Academic Career of Olga Nagy in the Light of Her Posthumous Book, Vallomások (2010)." Hungarian Cultural Studies. e-Journal of the American Hungarian Educators Association, Volume 6 (2013): http://ahea.pitt.edu DOI: 10.5195/ahea.2013.122

been amputated from Hungary's body," and, most stridently, "we live among the barbaric Balcanians" (Cs. Gyímesi 1985, 49-59; 1992, 2004; Fábián 1999; Hadházy 2000, 162-169; Pomogács and Fehér 1973; Pomogács 1983, 1990, 56-70, Tóth 1974, 54-57; 1999, 114-128). The long-lasting anger expressed in anti-Romanian discourses blocked and, for some academicians, continues to block any analytic view of the Romanian cultural context in which they have been living now for ninety years. For example, most monographs written about villages with a mixed population ignore the Romanian population and their culture, or depict it only as something that "contaminates" the Hungarian culture. Among the Hungarian population intermarriage is considered a threat, as is what is termed elrománosodás, which is a reference to the growing Romanian population. Even though Olga Nagy was considered one of the more open-minded scholars who actually also considered Romanian folklore in some of her work, her writing, too, reflects this hostile anti-Romanian discourse. To her, preserving, protecting saving and maintaining the Hungarian culture was like a religious mission. As a result of this, her language and rhetoric often sounds like a sermon rather than academic discourse.

For Nagy, Transylvanian-Hungarian folklore was the very root of Hungarian culture. Since she had studied ethnography at the time of Transylvania's re-annexation to Romania, during the first years of communism, a period considered traumatic for Transylvanian Hungarians, she began her ethnographic and folkloristic fieldwork armed with the extreme nationalistic ideology of saving Hungarian-Transylvanian culture from modernity and foreign threats. She studied the type of ethnography that from the nineteenth century sought to discover, save, preserve and cultivate what was considered "ancient," "authentic," "real," "valuable" and "pure" Hungarian treasures of folklore. The main perception of folklore at the time was that it was the oral folklore of the peasantry that carried the primordial state of national culture, untainted by foreign influence and the artificiality of the higher classes. Nevertheless, collectors censored and edited the material collected, preferring folk songs, ballads, and folktales (obviously they edited these as well), while ignoring folkloric phenomena considered less aesthetic or crude, such as short stories, jokes, gossips, or songs and tales that sounded too "foreign" or new to fit into the root-seeking national narrative. Such a faux-romantic attitude in the folklore collecting of peasant culture has survived in Transylvania long after it was totally outmoded in the field of folklore elsewhere because it served as a sort of naive resistance to the modern, industrialized, urban, and multi-lingual world of post-World War II Romania. Basically, since Transylvanian intellectuals viewed folkloric tradition as the source of national Hungarian culture, they perceived safeguarding it as the key to remaining Hungarian in a Hungarian minority situation, an attitude called helytállás, megmaradás [resistance], which means literally "standing still in (our) place," or "persisting in staying, no matter what, maintaining our national integrity." This moral framework of resistance and emigration (even to the "mother country" of Hungary), was perceived as a breach, while assimilation to or cooperation with anything Romanian was considered disloyalty or even treason.

Folklore studies, then, were a means of sustaining a Hungarian identity as a minority within Romania, and they remained committed to the raison d'être of Olga Nagy's career to the very end. In her work, she assumed that the basic framework of folklore was national and ethnic. In this, she, like many others, separated Hungarian folklore from its multi-lingual culture, despite the fact that she conducted her research in a dynamic multi-lingual, multi-ethnic region of the Carpathian basin, a region where more than fifty ethnicities coexisted and interacted. Nagy could not but acknowledge that the materials she documented obviously existed in many ethnic variations, and yet her main framework remained highly ethnocentric, even after the 1969 
Vincze, Kata Zsófia. "Transylvanianism, Nationalism, Folklore: The Academic Career of Olga Nagy in the Light of Her Posthumous Book, Vallomások (2010)." Hungarian Cultural Studies. e-Journal of the American Hungarian Educators Association, Volume 6 (2013): http://ahea.pitt.edu DOI: 10.5195/ahea.2013.122

publication of Fredrik Barth's (1969) ethnic paradigm shifting ethnological study on the constant mutual interaction of cultures. Barth's work showed that the dynamics of multi-ethnic cultures throughout centuries make it nigh impossible to credit a song, a tale, a tradition or belief to a single ethnicity, and yet the emotionally-charged Transylvanianism blinded scholars to accept this ethnic paradigm shift that happened in social sciences all over Europe in the 1970s.

The significance of Olga Nagy's later work lies in its dismantling of illusions about folk and rural culture. At this stage, instead of trying to collect the "ancient", "authentic", "pure," and beautiful romanticized and idealized national gems and treasures of folk culture, Nagy realized through her own empirical research in real villages during real fieldwork that the live rural culture, the lived folklore, was not necessarily aesthetic, pure, innocent, or morally immaculate (see Nagy 1969; 1974; 1978). However, before this recognition, at the start of her career, Nagy searched for beautiful fantastic fairytales, beautiful folksongs and ballads, and when she could not find them or when what she found was not what she expected (based on her folklore studies), she took it upon herself to write "nice" stories for the children instead. This is almost the same as what the other great "authentic" predecessor folklore-collectors did: stylizing, aestheticizing and creating folk-like tales that met their own expectations of their "genuine" national folklore. That is, regardless of the shortcomings of Nagy's early work, throughout her academic career in folklore we can witness the so-called "empirical turn" from romanticizing the aesthetic expressions of folklore and idealizing peasantry to the critical and social scientific approach. In the 1970s Nagy organized a village research group to visit a Transylvanian village where fieldwork and participant observation yielded significant academic results. The volume resulting from this fieldwork, Világgá futó szavak [Fleeing Words] focused attention on the living, interactional nature of folk culture (such as the ways in which men and women construct memories, the sociography and value system of rural labor, the norms and deviations of coexistence, and folk culture's views on life). It was in this study that Nagy first discussed the illocutionary role and everyday forms of "living speech," rejecting former ideas of clean and flawless artistic structures. Another, more theoretical and synthesizing work of hers was her book published in 1993 Táltos és Pegazus [Steed and Pegasus], which argued for the unity of culture and the constant interaction and active relationship between folk and elite registers (in this case, between folklore and written literature). Last but not least, Nagy's 2001 Erdélyi sors: tegnap, ma, holnap [Transylvanian Fate: Yesterday, Today, Tomorrow] presents Transylvanian ideology between the two World Wars as expressed in myths, in narrative behavior and memory, and in the collective system of values.

Finally, it was not through complex and elaborate theories but by empirical tests of her fieldwork materials that Nagy realized, almost intuitively, that the rural people are not diamonds in the rough. She began to analyze within the framework of folklore that people violate the traditional moral laws (see Nagy 1989), that they curse - and that therefore curses are a folklore genres - sing obscene songs, that their daughters lose their virginities prior to the wedding night, that her informants are uneducated, coarse and emotionally barren, that they beat their wives and abuse their children, marry for interest and will do anything for money, just like anybody else. She likewise realized that the stories of the people were not necessarily folkloric treasures that can be systematically structured in a perfect genre hierarchy; nor are they chiseled and perfectly structured aesthetic expressions of culture, but rather show all the characteristics of living texts that, by default, are characteristic of folklore (such as adaptation and variation). Nagy had to come to realize that, thematically, these living stories were not about enchanted princesses and fantastic adventures but about poverty, hard work, abortions, tragic marriages, hopelessness, 
Vincze, Kata Zsófia. "Transylvanianism, Nationalism, Folklore: The Academic Career of Olga Nagy in the Light of Her Posthumous Book, Vallomások (2010)." Hungarian Cultural Studies. e-Journal of the American Hungarian Educators Association, Volume 6 (2013): http://ahea.pitt.edu DOI: 10.5195/ahea.2013.122

horrors of abuse, poverty, brutal husbands, unfaithful wives, squandering sons and troubled relationships. She also had to realize that, formally, the stories she collected sometimes carried the traces of folktales learned in school, the short stories of Boccaccio known from a volume that circulated in one village and read by some people, and later they were also influenced by current movies and soap operas (see Nagy 1977, 1983, her two volumes on the folklorization of Boccaccio's Decameron). In the above-mentioned highly emotional national context, questioning the moral and aesthetic values of peasant culture, criticizing the cruelty of rural life, or describing it in naturalistic, realistic terms was considered heresy — an attitude that still persists today even in academic discourse. Despite of the harsh criticism she received, Nagy's books were quiet successful, especially in Hungary. Articulating a nostalgia for the lost Transylvania and Transylvanians, her books served as a source of authenticity of Hungarian culture, not only for academics, but for a lager public as well.

In her Vallomások, published posthumously, Olga Nagy reflects on her former work from a highly subjective, confessional position, rejecting the requirements set for normative academic argumentation and writing in essayistic style. There is hardly a single page that does not contain some expression of bitterness, concern, anxiety, hopelessness, and helplessness in her discussion of what she sees as her own self-sacrificing role in defending Hungarian Transylvanian culture. She presents the fate of the Hungarian minority, the life of the peasants and especially the situation of women, and her own role as researcher in a vulnerable climate full of difficulties, struggle, helpless pain and constant suffering from social political and economic suppression. She describes this world as "tangled," and "dreadful" (348), and the era as "hopeless" and as "a dead-end" that "promises no good" (358). She often complains about the "money-grubbing" of people, the greedy egoistic "Western world" and publishers, who are the sworn enemies of cultural values, and the terrible dangers that threaten Hungarian national identity and culture (316). At first glance, the volume seems somewhat bittersweet, naive and more like a tragic confession of the wife of a Hungarian (Transylvanian) minister stuck in Romania than the selfreflexive account of an academic researcher. One example of this is Nagy's lengthy diatribes in parentheses in the Vallomások about her thoughts on God, heaven and hell (349), and motherhood, which she repeatedly calls the mandatory "sacred duty" of women (348). Another is the way she describes how she considered "even" gypsies her friends after some "nice experiences," that she "had no problems with Jewish people," and even resented the "alarming and malicious prejudices of anti-Semitism" (353), but still considers the homosexuality of the ancient greats "sick" and "perverted" (345). Considering her weak and already long outdated arguments (such as "women are also capable of analyzing great horizons and opportunities and of synthesis" (344), or "indeed, the list of women determining and enriching the entire human culture of the world would be a long one" (344)), it would be too easy to label her outlook as simplifying or dated, when, in fact, in spite of her limitations, she nevertheless brought about, or at least significantly contributed to, a cultural shift in the field of ethnography in Romania. Her outdated views - casually strewn around her academic books - were not considered the least bit shocking or scandalous to Romanian Hungarian or Hungarian thinking at the time, neither at the time of writing in 1999 nor in 2011 when the book was published. In fact, in the academic circles of her time, Olga Nagy was considered exceptionally open-minded and even too progressive. According to some of her critics, she was "aggressively feminist."

The reason that Nagy can, in some sense, be called a "feminist" is that she gave direct voice to some of her female informants. She didn't just publish the folktales and songs that these women told and sang to her, but she also encouraged them to tell and write the stories about their 
Vincze, Kata Zsófia. "Transylvanianism, Nationalism, Folklore: The Academic Career of Olga Nagy in the Light of Her Posthumous Book, Vallomások (2010)." Hungarian Cultural Studies. e-Journal of the American Hungarian Educators Association, Volume 6 (2013): http://ahea.pitt.edu DOI: 10.5195/ahea.2013.122

lives, upbringing, parents, marriages, relationships. One of her main informants, Klára Győri, was living in a village that was considered the most isolated traditional village in Transylvania, one that was once an old small mine town, where people up until today are still wearing the eighteenth century popular red and black colored traditional folk costumes (as a symbol of blood and grief over the Tatar massacres, especially the one from 1717). Because of its isolated traditionalism, this village in particular was the land of cultural authenticity for Hungarian intellectuals thirsty for "pure" and "ancient" Hungarian culture that is not "infected" by the new Romanian assimilation policy of the communist rule. The shock, therefore, was enormous when from this village Klára Győri, encouraged and helped by Olga Nagy, published her life story. Györi writes about how she grew up in terrible poverty, like most children in the village, and how, at the age of ten, she became a maid in the nearby city, Kolozsvár. She writes about child labor and exploitation, the helpless situation of young women without any rights in the family, and how she was dreaming about a better life. She describes how she got married to a wealthier man, because he had a big "stone house," but all her life she felt utterly disgusted by him. She described every intimate moment, including their wedding night, that she had to spend with him, like a horrifying experience that she tried to constantly avoid. In this memoir Györi describes a world where the law and the customs favor the men, and the heritage automatically goes to men, and where women are therefore always dependent on men and practically live like slaves of their fathers, brothers, husbands and even their sons. Györi also writes about her feelings as a young woman for other men, but since she was dependent financially and lived in a village where the local customs limited her opportunities, she had to bear her brutal husband.

Nagy wrote the foreword for Györi's book and she edited the manuscript, but everyone in academia knew that Klára Győri was her informant from the village of Szék for years (Györi 1975), who told her many, many folktales, beliefs, proverbs etc. Through the context of real life stories this classical folkloric genre gained a different sense. After Nagy's real (life) story collections, the folklore texts cannot stand anymore alone ripped out of their living social context. With the rural women's life stories, a new school started in folklore studies that developed the life-story methodology that contextualizes every folkloric phenomena in the life story and social context of the informant. The stories of Nagy's informants were written, as opposed to the classical folklore that was supposed to be oral. Obviously today, we no longer think that the memoir had the style of oral stories, and understand that this type of narration was on the border of the oral folklore and written narration. Overall Nagy tried to show the rural culture in it's raw holistic complexity and not as l'art pour l'art literature or folk art.

Due to this new life-story methodology, and in particular the living folklore concept and her works on exposing the difficulties women were facing, Nagy came under a public crossfire upon her publication of the life stories of Romanian Hungarian Transylvanian rural women. These accounts were severely criticized, for example by István Szőcs, the chief editor of the leading literature magazine Utunk [Our Path]. Szöcs - among others - accused Nagy of fabricating the memoire of Klára Győri. Shocked by the oppression, brutality and sexual deviances described by a "simple peasant woman" in this book, Szöcs (1976) claimed that only an emancipated feminist could have written or manipulated the poor peasant woman to write such exhibitionist, cruel, "pure obscenity" that humiliates womanhood. Szöcs denied that this type of narrative (what we today call oral history) can be subject of ethnologic analysis. While he mocked the book's feminist style, he definitely questioned its legitimacy in folklore, ethnography or ethnology mainly because Nagy extended the concept of folklore from the classic literaturelike folk treasures to the realistic narrations. 
Vincze, Kata Zsófia. "Transylvanianism, Nationalism, Folklore: The Academic Career of Olga Nagy in the Light of Her Posthumous Book, Vallomások (2010)." Hungarian Cultural Studies. e-Journal of the American Hungarian Educators Association, Volume 6 (2013): http://ahea.pitt.edu DOI: 10.5195/ahea.2013.122

Olga Nagy’s greatest contribution with editing and publishing Klára Győri's memoir was that she was the first to focus attention on the situation of rural Transylvanian Hungarian women. Afterwards, she collected and published many shorter life stories told by rural women (see, Asszonyok könyve [Women's Book] from 1989), stories which long kept dark secrets of women that the larger public was not familiar with. Interestingly the term confession is a reoccurring title in the memoirs written by rural women that Nagy recorded, collected, edited and published. Confession as testimony suggests that these women revealed a secret and broke a taboo by talking about their horrifying life, the abuse and suppression. For example, Nagy's interviewee Zsuzsa György's memoir is entitled Küzdelmes élet, egy parasztasszony vallomásai [A life of struggle: A peasant woman's confession], Rózsi Kocsis's book's title is: Nyitott könyv a lelkem. Egy anya vallomásai [My heart is an open book: A mother's confession] and, from the same author, Megszépült szegénység. Vallomások a gyermekkorról [Beautiful poverty: Confessions on childhood]. As we can see even from these titles, the stories collected by Nagy on womanhood and the life stories of rural women are about bitter unhappy lives of women, resignation and suffering of domestic violence. The above mentioned Klára Győri's memoire entitled Kiszáradt az én örömem zöld fája [The joy of my three has dried out] introduces her confessions with this sentence: "It hurts, that no matter how deep I dig in my past, I cannot find one single good memory in it" [Fáj nekem, bárhogy kutatom múltamat, egyetlenegy jobb emléket nem találok közte] (Györi 1975, 5).

In her Vallomások, Nagy invariably speaks of women as oppressed "poor women" who never have the chance to be happy and do not even know what happiness, pleasure or joy is, who live their bitter lives in pain and difficulties, who "endure" bearing motherhood as a duty and a tough sacrifice that is mandatory for women regardless of their jobs, social status or role in the society (298).

Bitterness - as she quotes one of her interviewers - "gnaws at them like wood-worms," and the most prevalent adjective to describe their meals are "scant" and "miserable" (317). The women she interviewed personalize their troubles as living creatures, euphemizing fear, cruelty and misery in what Nagy paradoxically calls these dark expressions "pretty metaphors " referring to their poetic aspect (318). Among these people, women as victims of the society, victims of their family, are working, toiling and surviving in deep unhappiness, never receiving any love or kindness from those for whom they work unconditionally (292), all aptly summarized in the old saying, which goes az asszony verve jó [women are best beaten] (on folkloric expression of wife battering, see Vasvári 2004, 313-336). In this world, men, parents and fathers are austere, cold, brutal and unfeeling, and the sacrifices and work of their womenfolk are not rewarded "with so much as a kind word" [egy jó szót nem mondott] (292). Nagy shocked the public by talking about the abuse and violence among the formally romanticized peasantry. Beating women and children was completely accepted, justified and so common that no one actually mentioned it while thousand of rural studies, village monographs were published. No analysis was written about women's abuse despite the fact that there are many folklore treasures, ballads, songs, sayings, about beating women.

Olga Nagy was the first academic in the Hungarian language to depict the folk, and especially women, as suffering victims of constant exploitation, as helpless and often immensely ignorant, as emotionally unsophisticated, and as rough but always in pain and misery. It was, finally, her later works that dispel the illusion of idealized folk and folklore that saved Olga Nagy from becoming an insignificant, dilettante folklorist and enthusiastic amateur ethnographer and becoming rather a leading figure of the academic empirical cultural turn through her 
Vincze, Kata Zsófia. "Transylvanianism, Nationalism, Folklore: The Academic Career of Olga Nagy in the Light of Her Posthumous Book, Vallomások (2010)." Hungarian Cultural Studies. e-Journal of the American Hungarian Educators Association, Volume 6 (2013): http://ahea.pitt.edu DOI: 10.5195/ahea.2013.122

fieldwork and participant observation. The same empirical turn that Olga Nagy inspired in Hungarian ethnology, happened at roughly the same time in German Volksunde (ethnography/folklore/ethnology), although there in a much more reflective and analytic academic context. Nagy most probably had very little or no access to the publications of Frankfurt or Berlin University. Compared to the academics of her time, Nagy was considered "progressive." Ferenc Pozsony, a leading scholar in Transylvanian ethnology, believes that Nagy's scholarly achievements regarding the oppressed women align her works with the modern views of contemporary Anglo-Saxon social anthropology (Pozsony 2007, 757-760).

Olga Nagy's contribution to modern ethnology comes in the form of her many case studies that completely dismantle the aesthetic expectations of Transylvanian ethnographers and folklorists toward folk culture as well as their idealized projection on and selective processing of folk art. She does away with the crystal clear demarcations between folklore, popular culture, and high culture, and reexamines how researchers' fixed genres and aesthetic views of folklore do not work in living oral tradition. Most importantly, she shows the cultural process whereby "traditional structures" and functions transform into phenomena that we currently see in living popular culture. In her case studies, she analyses how "the fantasy of fairytales meets realism," how stories are reduced to jokes, how legends are replaced by rumors, and how pulp fiction and mass education influence and transform rural oral tradition. The significance of her work is that she demonstrated that it is not sacrilege to observe, research and publish the less sophisticated and less "artistically classically valuable" rural culture - accepting that they are simply the reality and part of changing culture. Reflecting on her own career in her Vallomások, Nagy considers publishing as her "moral duty," her determined task, her "fate" [sorsszerüség, sorsszerü kötelesség] — terms often used by the Hungarian intellectuals from the 1920s up until today. She viewed herself as doomed to sacrifice herself for the minority causes, for example, in how she presents her own family's material poverty as beautiful and heroic. Poverty is a sort of implicit underlying value and sacrifice and, in Eastern-European cultural thinking, almost a moral prerequisite for having a responsible life as an intellectual. Contrasting materialism, Nagy's confessions conclude that the "fate" of an intellectual is a moral intellectual fight for national justice, a struggle to maintain the national identity, and "resistance" in a hostile environment.

\section{Works Cited}

Barth, Fredrik. 1969. Ethnic groups and boundaries. The social organization of culture difference. Oslo: Universitetsforlaget.

Cs. Gyímesi, Éva. 1985. "Egy létszimbólum színe és visszája [An existential symbol’s face and its back]." Életünk 1: 49-59; . 2004. "Helyzet és helyzettudat." Transzcendens remény. A Limes-kör

dokumentumai [Status and situation awareness. The documents of Limes-circle].19851989. Csíkszereda. . Gyöngy és homok. Ideológiai értékjelképek az erdélyi Magyar irodalomban [Pearls and sand. Ideological value-symbols in the Transylvanian Hungarian literature]. Bukarest: Századunk.

Fábián, Ernő. 1999. A megmaradás parancsolatai. Esszé az erdélyiségröl mint politikai entitásról [The commandments of Preservation. Essay about Transylvania as a Political Entity]. Budapest.

Hadházy, Zsuzsa. 2000. "Kérdések és válaszok. Az Erdély-vita összefoglalása 
Vincze, Kata Zsófia. "Transylvanianism, Nationalism, Folklore: The Academic Career of Olga Nagy in the Light of Her Posthumous Book, Vallomások (2010)." Hungarian Cultural Studies. e-Journal of the American Hungarian Educators Association, Volume 6 (2013): http://ahea.pitt.edu DOI: 10.5195/ahea.2013.122

[Questions and Answers. Summary of Transylvania discussion]." Erdélyi Magyar Évkönyv. Kolozsvár-Temesvár 162-169.

Keszeg, Vilmos. 1994. "Táltos és Pegazus [Steed and Pegasus]." Korunk 5. 10: 118-121. . 2000. "Egy barátság és egy életmü története [A story of a Friendship, a Story of Life-long Work]. Látó 11. 1: 102-106. 2002. "Nagy Olga." Romániai magyar irodalmi lexicon [Romanian-Hungarian literary Lexicon]. 4. Bukarest-Kolozsvár: Erdélyi Múzeum-Egyesület-Kriterion. 61-64.

Keszeg,Vilmos and Viga Gyula. (eds.) 2001. "Ünnepi írások a 80 esztendős Nagy Olga tiszteletére [Essays in Honor of Olga Nagy's eightieth Birthday]." Néprajzi Látóhatár 14.

Kocsis, Rózsi. Megszépült szegénység. Vallomások a gyermekkorról [Beautiful Poverty. Confessions on Childhood]. Bukarest: Kriterion. 1988.

Nagy, György. 1993. "A kisebbségi helytállástól a közösségi desirabilitásig és vissza. A transzszilvanista ideológiáról [From Standing still as a Minority to community desirability and back]." Korunk 1: 18-32.

Nagy, Olga. 1969. Lüdérc sógor. Erdélyi magyar népmesék [Lüdérc, Incubus Brother in law. Transylvanian Hungarian Folktales]. Bukarest: Ifjúsági Könyvkiadó. . 1974. Hösök, csalókák, ördögök. Esszé a népmeséröl [Heroes, tricksters, devils. Essay on Folktales]. Bukarest: Kriterion Könyvkiadó. 1978. A táltos törvénye. Népmese és esztétikum. Bukarest: Kriterion Könyvkiadó. . 1977. Paraszt dekameron. Válogatás széki tréfákból és elbeszélésekböl

[Peasant Decameron. Selection of Jokes and Anecdotes from Szék]. Budapest: Magvető. . 1983. Újabb paraszt dekameron. A szerelemröl és a házasságról [The new

Peasant Decameron. About love and marriage]. Budapest: Magvető. . 1988. Asszonyok könyve. Népi elbeszélések [Women's book. Rural stories].

Budapest: Magvetö. . 1989. A törvény szorításában. Paraszti értékrend és magatartásformák

[Restrictive laws. The rural value system and behavior]. Budapest: Gondolat. 1990. Világgá futó szavak. Havadi beszélgetések [Fleeing words. Dialogues in

Havad]. Budapest: Szépirodalmi Könyvkiadó, 1990. . 1991. Gyónás [Confession]. Buapest: Európa kiadó. 1993. Táltos és Pegazus [Steed and Pegasus]. Budapest: Holnap. 1999. A mítoszok nem halnak meg [Myths don't Die]. Esszé. Budapest:

Holnap. 1999. Pályakép fénnyel és árnyékkal. Egy néprajzos emlékezései [Career

Portrait with Lightness and Darkness. Memories of an Ethnologist]. Székelyudvarhely. 2001. Erdélyi sors. Tegnap, ma, holnap [Transylvanian fate. Yesterday, Today,

Tomorrow]. Budapest: Gondolat. . 2010. Vallomások [Testimony]. Budapest: Luna Kiadó.

Pomogáts, Béla and E. Fehér, Pál. 1973. "Vita a transzilvanizmusról [Debate on Transylvanianism]." Kritika 8: 8

Pomogáts, Béla. 1983. "A transzilvánizmus Az Erdélyi Helikon ideológiája [Transylvanianism. The Ideology of the literary journal Erdélyi Helikon]." Irodalomtörténeti Füzetek. Budapest. 
Vincze, Kata Zsófia. "Transylvanianism, Nationalism, Folklore: The Academic Career of Olga Nagy in the Light of Her Posthumous Book, Vallomások (2010).” Hungarian Cultural Studies. e-Journal of the American Hungarian Educators Association, Volume 6 (2013): http://ahea.pitt.edu DOI: 10.5195/ahea.2013.122

. 1990. "Szabédi László a transzszilvanizmusról [László Szabédis

Transylvanianism]." Új Erdélyi Múzeum 1 (1990): 56-70;

Szőcs, István. 1976. "A dokumentumtól az irodalomig [From the Document to fiction]." Utunk 23: 2.

Tóth, Sándor. 1974."A transzilvanizmus fogalmáról [About the idea of Transylvanianism].” Tiszatáj 1: 54-57. (alias Sárréti, Sándor) . 1999. A transzszilvanizmus színeváltozásairól. Források és stratégiák [The changing Face of Transylvanianism. Sources and Strategies]. Csíkszereda. 